\title{
Nitrogen Sources, Transport and Processing in Peri-Urban Floodplains
}

\author{
D C Gooddy ${ }^{\mathrm{a}^{*}}$, D M J Macdonald ${ }^{\mathrm{a}}$, D J Lapworth ${ }^{\mathrm{a}}$, S A Bennett ${ }^{\mathrm{b}}$ and K J Griffiths ${ }^{\mathrm{a}}$ \\ ${ }^{a}$ British Geological Survey, Maclean Building, Wallingford, Oxfordshire, OX10 8BB, UK \\ ${ }^{b}$ British Geological Survey, Keyworth, Nottingham, NG12 5GG, UK \\ ${ }^{*}$ Corresponding author
}

Email address dcg@bgs.ac.uk

\begin{abstract}
Peri-urban floodplains are an important interface between developed land and the aquatic environment and may act as a source or sink for contaminants moving from urban areas towards surface water courses. With increasing pressure from urban development the functioning of floodplains is coming under greater scrutiny. A number of peri-urban sites have been found to be populated with legacy landfills which could potentially cause pollution of adjacent river bodies. Here, a peri-urban floodplain adjoining the city of Oxford, UK, with the River Thames has been investigated over a period of three years through repeated sampling of groundwaters from existing and specially constructed piezometers. A nearby landfill has been found to have imprinted a strong signal on the groundwater with particularly high concentrations of ammonium and generally low concentrations of nitrate and dissolved oxygen. An intensive study of nitrogen dynamics through the use of $\mathrm{N}$-species chemistry, nitrogen isotopes and dissolved nitrous oxide reveals there is little or no denitrification in the majority of the main landfill plume, and neither is the ammonium significantly retarded by sorption to the aquifer sediments. A simple model has determined the flux of total nitrogen and ammonium from the landfill, through the floodplain and into the river. Over an $8 \mathrm{~km}$ reach of the river, which has a number of other legacy landfills, it is estimated that 27.5 tonnes of ammonium may be delivered to the river annually. Although this is a relatively small contribution to the total river nitrogen, it may represent up to $15 \%$ of the ammonium loading at the study site and over the length of the reach could increase in-stream concentrations by nearly $40 \%$. Catchment management plans that encompass floodplains in the peri-urban environment need to take into account the likely risk to groundwater and surface water quality that these environments pose.
\end{abstract}

Keywords: floodplain hydrogeology, groundwater surface water interaction, urban groundwater, nitrogen isotopes, nutrient fluxes

\section{Introduction}

In recent decades anthropogenic inputs of $\mathrm{N}$, for food production by intensive agriculture and urbanisation, have caused increases in macronutrient fluxes, and have led to widespread $\mathrm{N}$ pollution of aquatic systems (Foster et al., 1982; Burt et al., 2011; Whitehead et al., 2012; Lapworth et al., 2013). This is a global issue with implications for food production and security, water quality and land management/planning (Galloway., 1999; Galloway et al., 2004). In Europe and North America there have been a series of policies and accompanying regulations which have focused on reducing point and diffuse $\mathrm{N}$ and $\mathrm{P}$ pollution and associated problems of eutrophication and ecological degradation of freshwaters. For example, the European Water Framework Directive (WFD 2000) has the aim for 
fresh and marine waters to reach 'good ecological status' by 2015 .

The zone of transition from rural to urban land-use is often referred to as the peri-urban area. Unlined waste sites or landfills are a common source of $\mathrm{N}$ and $\mathrm{C}$ inputs to surface and groundwaters in peri-urban floodplains (Wakida and Lerner, 2005; Corniello et al., 2007). In Europe and North America there is a legacy of historic pollution from these sites (e.g. Heaton et al., 2005; Lorah et al., 2009). As such, landfill leachate plumes may contain high dissolved organic $\mathrm{C}$ (DOC) and $\mathrm{NH}_{4}{ }^{+}$ concentrations as well as ferrous iron, chloride and bicarbonate relative to natural floodplain conditions (Lorha et al., 2009). These commonly develop a series of distinct redox zones (Lyngkilde and Christensen, 1992). In such systems, dilution, sorption and denitrification may be effective attenuation processes within the shallow groundwater system. The attenuation of $\mathrm{N}$ pollution from landfills, as well as other sources within peri-urban settings, requires fluctuations in redox conditions. These may be expected in floodplain settings due to rapid changes in water levels and episodes of surface water recharge and inundation.

Nitrogen in the form of ammonium $\left(\mathrm{NH}_{4}{ }^{+}\right)$is present naturally in groundwater as a result of anaerobic degradation of organic matter, and in the form of nitrate $\left(\mathrm{NO}_{3}{ }^{-}\right)$from the microbial oxidation of the $\mathrm{NH}_{4}^{+}$. However, $\mathrm{NH}_{4}^{+}$and $\mathrm{NO}_{3}^{-}$also occur in groundwater from anthropogenic sources. High concentrations of $\mathrm{NH}_{4}{ }^{+}(10-1000 \mathrm{mg} / \mathrm{L})$ have been found in groundwaters impacted by landfill leachates and as a result of domestic and agricultural waste water disposal practices (Gooddy et al., 1998; Lawrence et al., 2000; Christensen et al., 2001; Heaton et al., 2005). High concentrations of $\mathrm{NO}_{3}{ }^{-}$are typically association with diffuse agricultural pollution from fertilisers (Oaks et al., 1981; Addiscott et al., 1991) although oxidation of anthropogenic ammonium sources also causes high $\mathrm{NO}_{3}{ }^{-}$ concentrations (Gooddy et al., 2002).

Ammonium transport in the subsurface may be retarded by sorption (Ceazan et al., 1989; Buss et al., 2004). Both $\mathrm{NH}_{4}^{+}$and $\mathrm{NO}_{3}^{-}$can be attenuated through microbially-induced transformations (DeSimone and Howes, 1998). Ammonium oxidation commonly occurs in conjunction with oxygen reduction and is termed nitrification. This results in the production of nitrite $\left(\mathrm{NO}_{2}^{-}\right)$followed by $\mathrm{NO}_{3}^{-}$.

$\mathrm{NH}_{4}^{+}+1.5 \mathrm{O}_{2} \rightarrow \mathrm{NO}_{2}^{-}+2 \mathrm{H}^{+}+\mathrm{H}_{2} \mathrm{O}$

$\mathrm{NO}_{2}^{-}+0.5 \mathrm{O}_{2} \rightarrow \mathrm{NO}_{3}^{-}$

In addition to degrading groundwater quality, $\mathrm{NO}_{3}{ }^{-}$and $\mathrm{NH}_{4}{ }^{+}$can both be substantial sources of $\mathrm{N}$ in surface waters receiving groundwater (Jackson et al., 2007). Therefore it is desirable that this nitrogen is completely removed from the aquatic system. This requires bacterially mediated denitrification to convert the nitrate through intermediate stages to nitrous oxide and ultimately to nitrogen gas (equation 3), which is a process requiring anaerobic conditions. This process is controlled by the availability of soluble carbon, redox status, $\mathrm{pH}$ as well as soil/groundwater water residence times and hydrology (Haycock and Burt 1993; Thomas et al., 1994; Burt et al., 1999; Gooddy et al., 2002).

$\mathrm{NO}_{3}{ }^{-} \rightarrow \mathrm{NO}_{2}{ }^{-} \rightarrow \mathrm{NO}+\mathrm{N}_{2} \mathrm{O} \rightarrow \mathrm{N}_{2}(\mathrm{~g})$

Therefore attenuation of $\mathrm{N}$ pollution from organic wastes requires alternating redox conditions, from oxidising to reducing, such as generated during water table fluctuations. Alternatively, through the anammox process, $\mathrm{NH}_{4}{ }^{+}$can be oxidised anaerobically to nitrogen gas through the reduction of $\left(\mathrm{NO}_{2}{ }^{-}\right.$ derived from $\mathrm{NO}_{3}^{-}$(see equation 3 above).

$\mathrm{NH}_{4}^{+}+\mathrm{NO}_{2}^{-} \rightarrow \mathrm{N}_{2}+2 \mathrm{H}_{2} \mathrm{O}$ 
Despite the environmental importance of $\mathrm{NO}_{3}{ }^{-}$and $\mathrm{NH}_{4}{ }^{+}$, there are few studies documenting their transport and reaction processes in aquifers (Heaton et al., 2005). Isotopic fractionation studies can provide an excellent tool for understanding $\mathrm{N}$ transport and speciation (Wassenaar, 1995; Böhlke et al., 2006). Isotopic fractionations have been reported for $\mathrm{NH}_{4}{ }^{+}$sorption to clays (Karamanos and Rennie, 1978), with the remaining $\mathrm{NH}_{4}{ }^{+}$in solution relatively depleted in ${ }^{15} \mathrm{~N}$. By contrast, nitrification results in a substantial increase in ${ }^{15} \mathrm{~N}$ for the remaining $\mathrm{NH}_{4}{ }^{+}$(Delwich and Steyn, 1970). Stable isotope ratios in $\mathrm{NO}_{3}^{-}$have often been used to distinguish various sources of $\mathrm{NO}_{3}^{-}$in groundwater, such as synthetic fertilisers and animal wastes (Gormley and Spalding, 1979; Flipse and Bonner, 1985). Denitrification causes an isotopic enrichment in the remaining nitrate (Mariotti et al., 1988). A disadvantage of the single isotope approach to denitrification studies is that process such as ammonia volatilisation can also lead to enrichment of ${ }^{15} \mathrm{~N}$ in the residual $\mathrm{NH}_{4}{ }^{+}$source material and in the $\mathrm{NO}_{3}{ }^{-}$produced during nitrification. However, by combining the $\delta^{18} \mathrm{O}$ of the $\mathrm{NO}_{3}{ }^{-}$, a more reliable indicator of the denitrification process is achieved (Böttcher et al., 1990; Wassenaar et al., 1995; Kendall., 1998; Fukada et al., 2004). The opposing isotope fractionation effects make it possible to distinguish between sorption, nitrification and denitrification as major processes affecting $\mathrm{N}$ distribution in a field setting through evaluating variations in concentration and isotopic composition.

Riparian floodplains provide an important interface between terrestrial and aquatic systems (Harms and Grimm 2008). Floodplain aquifers can be important sources of drinking water and sustain baseflow in surface waters, with important ecological implications (Sophocleous, 2002; MurrayHudson et al., 2006). However, globally, floodplains are increasingly being encroached and developed due to anthropogenic pressures including urbanisation and intensive agriculture (Tockner and Stanford 2002; Pinter 2005; Werritty 2006). In many parts of Europe, and elsewhere, there is a historical legacy of change in land use and associated historical pollution loading to floodplain groundwaters and surface waters (Burt et al., 2011; Stuart et al., 2011a). Peri-urban floodplains are therefore complex, in terms of spatial heterogeneity in land use and topography, and temporal variability in recharge and redox processes (Burt et al., 2002; Burt and Pinay 2005; Macdonald et al. 2012a; MacDonald et al., 2014).

Due to changing redox conditions, floodplains and riparian settings are considered hot-spots for nutrient attenuation (Devito et al., 1999; McClain et al., 2003; Harms and Grimm 2008). Groundwater levels within floodplain environments are typically shallow and responsive to recharge events. Vertical and spatial soil moisture conditions are also highly variable, and together these have important implication for attenuation of oxidised N (Burt et al., 1999). Periods of inundation may stimulate denitrification due to the mobilisation of $\mathrm{C}$ pools at shallow depths; during periods of low water tables denitrification may be restricted due to reduced $\mathrm{C}$ pools, low soil moisture and more oxidising conditions.

The important ecosystem services provided by floodplains and their general proximity to potentially damaging agricultural and urban nutrient sources means there is an imperative to understand nutrient processes, fluxes and attenuation mechanisms within. Due to the complex hydrogeology estimating the residence times of groundwaters and legacy nitrogen pollutants is challenging. There is therefore uncertainty as to the timescale for changes in management practices at the surface, reducing baseflow nutrient fluxes to surface waters (Wang et al., 2011; Stuart et al., 2011b; Jackson et al., 2008).

This paper examines the temporal and spatial variations in $\mathrm{N}$ species within a typical peri-urban setting in the floodplain of the River Thames, UK. The peri-urban hydrological setting, legacy of pollution, and dependent terrestrial ecosystems means the study is relevant across many industrialised and rapidly industrialising regions. The aim is to understand the water movement and redox status 
across the case study peri-urban floodplain and how this influences nutrient fluxes to the adjoining river. The objectives are to use geochemical indicators together with $\delta^{15} \mathrm{~N}$ of $\mathrm{NH}_{4}{ }^{+}$and $\delta^{15} \mathrm{~N}$ and $\delta^{18} \mathrm{O}$ of $\mathrm{NO}_{3}{ }^{-}$to: 1) evaluate the origin of the nitrogen in groundwater; 2) ascertain whether sorption, nitrification or denitrification were occurring to attenuate the nutrient loading; and 3) estimate the amount of nitrogen that is delivered to the river system.

\section{Materials and Methods}

\subsection{Study area}

The study focuses on a section of the floodplain of the River Thames in the vicinity of the city of Oxford in the southern UK (Figure 1). The study area, known as Port Meadow, is to the north-west of the historic city centre. Port Meadow is an area of communal grazing and is regularly flooded by the River Thames, which flows along its western border. Due to areas of persistent groundwater flooding, the meadow supports a large number of waterfowl. Port Meadow is part of the larger Oxford Meadows Special Area of Conservation (SAC). The study area (Figure 2a) also includes: the Burgess Field Nature Reserve, a former waste dump located to the east of Port Meadow; various tracts of land to the east, sited on the current floodplain, which were formerly the location of industrial landfills; the urbanised higher ground to the east of the floodplain; and the agricultural areas to the west of Port Meadow and the River Thames. The study area is bounded to the north and the south by urban developments.

The River Thames flows in a southerly direction through the city of Oxford (Figure 1). The mean annual flow of the Thames upstream of the study area is $18.48 \mathrm{~m}^{3} \mathrm{sec}^{-1}$ (Marsh and Hannaford, 2008). The baseflow index (the ratio of long-term baseflow to total flow) for the river at this location is 0.67 , reflecting the influence of influent groundwater, sourced from the limestone aquifers located in the headwaters, and the extensive floodplain gravel aquifers. The River Thames floodplain is approximately $2 \mathrm{~km}$ wide in the Port Meadow area, with a low gradient of less than $0.1^{\circ}(0.03 \%)$. Groundwater flow is predominantly north-east to south-west; Figure 2a includes groundwater level contours for a low-flow period. Normally groundwater flows into the River Thames from the northeast along the full reach within the case study area. Water management structures on the Thames a few hundred metres downstream of Port Meadow are a control on the hydrology of the area, by maintaining the river at relatively high levels during low-flow periods (Macdonald et al 2012a). In the furthest downstream reach of the River Thames in the study area this can cause a reversal in hydraulic gradient for a few weeks of the year, allowing eastward flow from the river into the floodplain deposits. The Seacourt Stream flows along the western edge of the floodplain. Flow in this stream comes in part from the River Thames to the north, controlled by a fixed head weir. The stream is also a major groundwater discharge line within the floodplain (Figure 2a); groundwater flows from the direction of Thames. The Oxford Canal runs along the eastern edge of the floodplain. There are also a series of drainage ditches across the floodplain.

The floodplain deposits within the Oxford Valley are made up of a shallow surface layer of finegrained alluvium, underlain by highly permeable sands and gravels (Figure 2b). The alluvium thickness can be up to 4 metres but is typically around $1.5 \mathrm{~m}$ (Macdonald et al., 2012a). The sands and gravels thickness is mostly within the range of 2 to 6 metres. The floodplain sediments are underlain by mudstones of the Upper Jurassic Oxford Clay Formation with some limited connection between the current floodplain sediments and second terrace gravels forming higher ground to the east of Port 
Meadow.

Port Meadow and the surrounding area have a long legacy of anthropogenic contamination with documented waste sites dating back to the late 1800s (Macdonald et al., 2012b). Burgess Field was used for domestic waste from 1937-1980. The waste here was dumped onto the floodplain surface with no underlying or lateral impermeable barriers apparent. The dump covers an area of $0.34 \mathrm{~km}^{2}$, and has an average height of $\sim 4 \mathrm{~m}$ above the natural ground level. The categories of waste reported to have been dumped there are: inert materials (soil, brick, concrete, glass, clay, sand etc.); semi-inert materials (wood, paper, cardboard, plasterboard, plastic, etc.); biodegradable wastes (food, sewage sludge, household, garden etc.); difficult wastes (e.g. tyres, sludges); and special wastes (hazardous chemical wastes, asbestos). Since closing, the waste dump has been grassed and planted with trees and shrubs. To the south of Burgess Field (Figure 2a) there are a number of other areas which received domestic, building and industrial waste during the late $19^{\text {th }}$ and early $20^{\text {th }}$ Centuries.

The pollutant load to the floodplain of the River Thames in Oxford is thought to be typical of a substantial proportion of the floodplain within the overall Thames catchment. To assess the proportion of the Thames floodplain that can be classed as peri-urban, within a GIS a $1 \mathrm{~km}$ buffer was delineated around the large urban areas defined within the Ordnance Survey Strategi dataset. The floodplain within the Thames catchment was approximated using the BGS Geological Indicators of Flooding dataset (Booth and Linley, 2010) and the interception between this and the peri-urban approximation calculated (Figure 3). The area of floodplain is estimated as $1619 \mathrm{~km}^{2}$; the area of peri-urban floodplain is $720 \mathrm{~km}^{2}$. This analysis indicates that significant areas within the Thames catchment can be classified as peri-urban and that insights from the Oxford case study will be have wider application.

\subsection{Sampling}

The sampling programme included 27 groundwater and 1 surface water sites across the study area (Figure 2a). The sites include a range of land uses and were located up flow-gradient of the landfill and floodplain, down flow-gradient of the landfill and three sites located in the landfill. The existence of the unlined Burgess Field landfill was anticipated to exert an influence on the chemistry of the area so two new transects running perpendicular from the landfill towards the River Thames were installed (PTM26-28, PTM29-31). Each transect contains three nests of four piezometers, installed to target different depth horizons and sample the landfill plume (Figure $2 b$ ). The piezometers within the nest were drilled separately, located within an area of approximately $4 \mathrm{~m}^{2}$. The depth horizons approximately correspond to the soil, the alluvium, the top of the gravels and towards the base of the gravels. The piezometers within a nest are identified by letters A (shallowest) to D (deepest). The use of transects of nested piezometers with discrete screened intervals provides a good constraint on the vertical and lateral changes in hydrogeochemistry. Additional details of the sample sites included in this study are given in Macdonald et al., 2012b. To assess the impact of seasonal fluctuations in the groundwater level on redox conditions and nutrient hydrogeochemistry, sampling was conducted at approximately quarterly intervals between May 2010 and May 2012, with a further sampling round in August 2013; in total 12 rounds were undertaken. The piezometer headworks were completed in a $100 \mathrm{~mm}$ diameter chamber below ground level, for aesthetic, security and safety reasons, and capped with a metal plate below a grass sod so that it can be located with a metal detector. During periods of flooding a short length of $150 \mathrm{~mm}$ diameter pipe is driven into the ground around the chamber, acting as a cofferdam and allowing water to be pumped away from the headworks before sampling. The design and use of the piezometers is shown in Figure 4. 
A minimum of three borehole volumes were purged from each groundwater sampling site, and samples were not collected until stable readings for $\mathrm{pH}$, specific electrical conductivity (SEC) and dissolved oxygen (DO) were obtained. Samples for chloride and nitrogen species were filtered at $0.45 \mu \mathrm{m}$ and collected in $30 \mathrm{~mL}$ plastic bottles. Samples for ${ }^{15} \mathrm{~N}$ analysis of $\mathrm{NH}_{4}$ or $\mathrm{NO}_{3}$ and ${ }^{18} \mathrm{O}_{-} \mathrm{NO}_{3}$ were collected on August $4^{\text {th }} 2013$ and filtered into plastic 1L bottles; the samples for $\mathrm{NH}_{4}$ analysis being acidified in the field with $\mathrm{HCl}$ to $\mathrm{pH} 2-4$. These samples were frozen to be defrosted just before analysis. Samples for dissolved gases were collected in sealed steel ampoules at the same time as the samples for isotopic analysis as well as at selected sites on two other occasions in July 2011 and October 2011.

\subsection{Chemical Analyses}

The samples were collected and analysed for $\mathrm{Cl}, \mathrm{NO}_{3}$ and $\mathrm{NO}_{2}$ using ion chromatography (IC), and $\mathrm{NH}_{4}$ by flow colorimetery. Field data including bicarbonate, $\mathrm{pH}$, temperature, specific electrical conductance (SEC), and dissolved oxygen (DO) were all determined at site, and a flow through cell was used for unstable field parameters to obtain representative in-situ values. Dissolved nitrous oxide was measured at the British Geological Survey's Environmental Tracer Laboratories (Wallingford, UK) by Gas Chromatography with an electron capture detector (ECD) and a $3 \mathrm{~m}$ Porapak ${ }^{\mathrm{TM}} \mathrm{Q}$ column held isothermally at $40^{\circ} \mathrm{C} . \mathrm{N}_{2} \mathrm{O}$ gas standards at $10 \mathrm{ppm}$ and $100 \mathrm{ppm}$ were used for calibration (Bedfont Scientific Limited, Rochester, England) and gave a linear response with the ECD. Analytical precision (1 SD) was typically $<1 \%$ (Gooddy et al., 2002).

Isotope preparation and analysis was carried out at the NERC Isotope Geosciences Laboratory (Keyworth, UK). Nitrate was separated on anion resins and prepared as silver nitrate using the method of Silva et al. 2000. Ammonium was converted to $\mathrm{NH}_{4} \mathrm{SO}_{4}$ on acidified quartz filter papers using a static ammonia diffusion technique (Sebilo et al. 2004). The filters were combusted to produce $\mathrm{N}_{2}$ for ${ }^{15} \mathrm{~N} /{ }^{14} \mathrm{~N}$ analysis. Ammonium and nitrate ${ }^{15} \mathrm{~N} /{ }^{14} \mathrm{~N}$ ratios were analysed by combustion in a Flash EA on-line to a Delta Plus XL mass spectrometer (ThermoFinnigan, Bremen, Germany). Isotope ratios were calculated as $\delta^{15} \mathrm{~N}$ values versus air (atmospheric $\mathrm{N}_{2}$ ) by comparison with standards calibrated against IAEA N-1 and N-2 assuming these had values of $+0.4 \%$ and $+20.3 \%$, respectively. Analytical precision (1 SD) was typically $<0.8 \%$, from repeat analysis of a sample. ${ }^{18} \mathrm{O} /{ }^{16} \mathrm{O}$ ratios of nitrate were analysed by thermal conversion to $\mathrm{CO}$ gas at $1400{ }^{\circ} \mathrm{C}$ in a TC-EA on-line to a Delta Plus XL mass spectrometer (ThermoFinnigan, Bremen, Germany). Isotope ratios were calculated as $\delta^{18} \mathrm{O}$ values versus VSMOW by comparison with $\mathrm{IAEA}-\mathrm{NO}_{3}$ assuming it had a value of $+25.6 \%$. Analytical precision (1 SD) was typically $<1.2 \%$.

\subsection{Flux calculations}

Darcy's Law was used to calculate the flux of a conservative tracer (in this case chloride) from the floodplain sediments into the River Thames along the reach parallel to the Burgess Field landfill. Parameters used to calculate the flux are given in Table 1 . The hydraulic conductivities (K) of the alluvium and the sands and gravels were estimated based on particle-size analyses of material obtained during the drilling of piezometers in Port Meadow, using the method of Boonstra and de Ridder (1981); the method relates K to the specific surface area of the sediment. Although sufficiently permeable to allow groundwater recharge to occur, the alluvium was estimated as having $\mathrm{K}$ values three orders of magnitude smaller than the gravel $\mathrm{K}$; the alluvium was therefore ignored in the calculation of lateral flux. Given the accuracy of the method, the average gravel $\mathrm{K}$ was rounded to the nearest 100 as was the range of potential $\mathrm{K}$ values (indicated in parentheses in Table 1). The river bed 
$\mathrm{K}$ was assumed to be equal to the gravel $\mathrm{K}$ as the correlation between river level and groundwater level in PTM25, which is adjacent to the river, was very high $\left(\mathrm{r}^{2}=0.99\right)$.

Geological logs of boreholes in the vicinity of the River Thames show an average thickness of alluvium of $0.8 \mathrm{~m}$ and depth to the base of the gravel aquifer of $4.4 \mathrm{~m}$; a river survey undertaken for the Environment Agency of England has the bed elevation at its deepest as $2.8 \mathrm{~m}$ below the floodplain ground level. Taking these into account, as well as a likely vertical groundwater flow component to the river, a cross-sectional area for groundwater inflow to the river from the gravel aquifer of $2.5 \mathrm{~m}$ was used. Groundwater and river level monitoring allowed the calculation of the head gradient towards the river; the direction of flow is approximately perpendicular to the river for the majority of the period being considered (Macdonald et al, 2012; Figure 2a). The gradient outside of periods of short-lived high river stage, ranges from 0.0008 to -0.0003 ; a median value of 0.0004 was used in the flux calculation. The total daily inflow of groundwater to the river along the Burgess Field reach was compared to the mean daily river flow, in Table 1.

Combining the inflows with the concentrations of dissolved species measured in boreholes between the landfill and the River Thames, enabled the flux of species into the river from the floodplain aquifer to be compared with the downstream flux in the river (see Results).

\section{Results}

Table 2 shows the range of results observed for selected determinants measured over the past three years. There is relatively little seasonal variation for any given site with the greatest temporal changes being seen when sampling has followed a recent heavy rainfall event (Macdonald et al., 2012b). Consequently, greatest temporal variation is observed in the shallow piezometers. Data for electrical conductivity shows this particularly well, with the majority of measurements made in August 2013 (square brackets) within 5\% of the mean conductivity sampled over the study period. Mean $\mathrm{pH}$ values are generally just below 7 with the highest values $(>7)$ found in the shallower $(<1 \mathrm{~m})$ piezometers and the two boreholes to the far south (PTM21 and OX14) and to the far north (PTM11) of the landfill. Highest $\mathrm{pH}$ values are found in the River Thames. Dissolved oxygen mean values are typically $<1 \mathrm{mg} / \mathrm{L}$ and often $<0.1 \mathrm{mg} / \mathrm{L}$ in the deeper piezometers, in the shallower piezometers DO is up to $10 \mathrm{mg} / \mathrm{L}$. The River Thames typically has DO concentrations at saturation for the atmospheric temperature in given season.

Nitrate concentrations range from a high of $\sim 30 \mathrm{mg} / \mathrm{l}$ in the river through to below detection for the majority of the piezometers (Table 3). The main exceptions are three monitoring boreholes (GBH3, 5 and 9) completed within the Burgess Field waste site where $\mathrm{NO}_{3}-\mathrm{N}$ concentrations range from $<0.01$ to $48 \mathrm{mg} / \mathrm{L}$. Within the nested transect boreholes (PTM26-28 and PTM 29-31), the shallow sites (B) have low $(<2 \mathrm{mg} / \mathrm{L})$ but uniformly higher mean $\mathrm{NO}_{3}-\mathrm{N}$ concentrations compared to deeper sites. Reflected by these generally low nitrate concentrations is the relative paucity of data for nitrate isotopes, with just 2 samples yielding enough nitrate to enable measurement and one of these being the river. $\delta^{15} \mathrm{~N}_{-} \mathrm{NO}_{3}$ values ranged from +10 to $+13 \%$ and $\delta^{18} \mathrm{O}-\mathrm{NO}_{3}$ ranged between +4 to $+6 \%$. This was compounded by the high organic carbon concentrations within the plume. These high concentrations coincided with a low redox status and negligible dissolved oxygen which was observed year round for most sites.

Nitrite concentrations generally fall below the detection limit of $10 \mu \mathrm{g} / \mathrm{L}$ although there are exceptions from the river Thames, the site at OX14 and the highest concentration occurring from one of the 
landfill monitoring boreholes. Highest concentration of $\mathrm{N}_{2} \mathrm{O}$, at nearly $200 \mu \mathrm{g} / \mathrm{L}$, also occurs in one of the boreholes adjacent to landfill. Other sites range from a near 'background' concentration of $0.2 \mu \mathrm{g} / \mathrm{L}$ to $\sim 54 \mu \mathrm{g} / \mathrm{L}$; the shallower transect boreholes are generally higher in concentration than the deeper transect boreholes (Table 3).

Ammonium concentrations show considerable variation from 0.05 to $99 \mathrm{mg} / \mathrm{L} \mathrm{NH}_{4}-\mathrm{N}$ with the highest concentration occurring in the landfill boreholes and the lowest in the River Thames (Figure 5). Concentrations are generally higher the closer the borehole is to the waste site and the deeper the borehole, with concentrations decreasing closer to the river. Concentrations from the waste site boreholes show considerable variation, with the highest concentration detected in the same site that also had the greatest amounts of $\mathrm{NO}_{3}-\mathrm{N}$ and $\mathrm{N}_{2} \mathrm{O}$. Similar to the $\mathrm{NH}_{4}-\mathrm{N}$ data, the $\delta^{15} \mathrm{~N}_{-} \mathrm{NH}_{4}$ values also show considerable variation from a minimum of $2.5 \%$ to a maximum of 19.2 of \%o (mean of $9.1 \% 0$ ). Values in the main transect vary much less, with a mean of $8.5 \%$ and minima and maxima of $6.9 \%$ and $9.2 \%$. The highest value occurs to the south of the main plume, whereas the lowest value occurs to the north. Values in the waste dump boreholes vary from $7 \%$ to $12.5 \%$.

Figure 6 shows filled contour plots of mean $\mathrm{N}^{-\mathrm{NH}_{4}}$ concentrations for the two transects within the floodplain along the flow gradient from the landfill site to the River Thames. There is a consistent

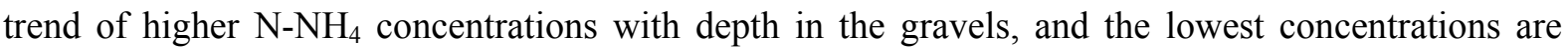
found in the two nests that are closest to the Thames. The highest concentrations are found in transect $\mathrm{B}$, between 100 and $200 \mathrm{~m}$ from the edge of the landfill rather than in the landfill and at a depth greater than $55 \mathrm{mAOD}$.

The steps in estimating the percentage of the $\mathrm{N}$ and $\mathrm{NH}_{4}-\mathrm{N}$ flux in the River Thames, due to that entering the river laterally from the floodplain sediments to the east, are set out in Table 3 . The total $\mathrm{N}$ and $\mathrm{NH}_{4}-\mathrm{N}$ groundwater influx is compared to the concentration within the River Thames by using a mean concentration in the river measured during the period of the study, and the long-term river flow upstream. Samples from the two borehole nests at the western end of the two transects (PTM26 and PTM29) provided an average deep gravel groundwater $\mathrm{NH}_{4}-\mathrm{N}$ concentration $(3.75 \mathrm{~m}$ borehole; $29.9 \mathrm{~g} / \mathrm{m}^{3}$ ) and total $\mathrm{NH}_{4}-\mathrm{N}$ concentration (average of 1.75 and $3.75 \mathrm{~m}$ boreholes; $21.6 \mathrm{~g} / \mathrm{m}^{3}$ ). Estimated fluxes of $\mathrm{NH}_{4}-\mathrm{N}$ in groundwater into the river along the Burgess Field reach are compared with the flux within the river; groundwater $\mathrm{NH}_{4}-\mathrm{N}$ fluxes account for up to $15 \%$ (depending on the input concentration) of the $\mathrm{NH}_{4}-\mathrm{N}$ in the River. Nitrate in the groundwater is negligible; total $\mathrm{N}$ in the river water is the sum of $\mathrm{NO}_{3}-\mathrm{N}$ and $\mathrm{NH}_{4}-\mathrm{N}$. Table 3 also compares the estimated total $\mathrm{N}$ flux of groundwater into the river with the flux within the river which is approximately two orders of magnitude smaller than that for $\mathrm{NH}_{4}-\mathrm{N}$.

\section{Discussion}

The spatial variability in groundwater $\mathrm{NH}_{4}-\mathrm{N}$ raises questions of source (i.e. does all the ammonium come from the landfill?) and attenuation mechanism within the floodplain sediments. A cross plot of $\mathrm{NH}_{4}-\mathrm{N}$ and $\mathrm{Cl}$ for all available data during the study, with sites grouped by different hydrological zones within the peri-urban floodplain, is shown in Figure 7. This shows the effect of dilution of the landfill contamination within the floodplain and the variability of $\mathrm{NH}_{4}-\mathrm{N}$ and $\mathrm{Cl}$ within each zone. The spread of data in Figure 7 can be understood in terms of ternary mixing between, i) groundwater leaching from the waste site with high $\mathrm{NH}_{4}-\mathrm{N}$ concentrations, ii) local shallow recharge to the floodplain gravels and iii) the River Thames. Ammonium contamination in the shallow gravels is 
diluted relative to the deeper gravels, increasingly so down the flow gradient towards the River Thames. The samples with lower $\mathrm{NH}_{4}-\mathrm{N}$ concentrations within the landfill sites are associated with low water level conditions. The shallow floodplain groundwaters have elevated $\mathrm{Cl}$ concentrations compared to other end members; this is perhaps evidence of evaporative enrichment of ponded surface water on the floodplain in the summer prior to recharge.

A cross plot of $\delta^{15} \mathrm{~N}^{-\mathrm{NH}_{4}}$ against $\mathrm{NH}_{4}{ }^{+}-\mathrm{N}$ (Figure 8) clearly shows how the majority of samples have $\delta^{15} \mathrm{~N}-\mathrm{NH}_{4}$ values that fall between $\sim 7$ and $10 \%$ and are fairly independent of concentration. The two major outliers from this trend are PTM11 and PTM25. PTM11 is thought to be largely up-gradient of the main contaminant plume and it would appear this is borne out from the isotopic data. The isotopic ammonium delta value coupled with the much lower concentration of ammonium here is more similar to a soil delta value rather than any influence of the landfill (Heaton, 1986; Kendall, 1998). Similarly, PTM25 is in close proximity to the River Thames, and this very high value is probably more indicative of faecal waste (Heaton, 1986; Kendall, 1998) from two possible sources: treated waste water input to the River Thames upstream of Port Meadow which can move into the floodplain sediments due to the hydraulic gradient reversal that can occur in the area of PTM25 during summer months; and waterfowl that congregate close to this area where groundwater flooding within the floodplain persists longest.

The landfill boreholes show some of the most interesting $\mathrm{N}$ transformation chemistry. GBH5 contains high concentrations of both nitrate and ammonia as well as significant concentrations of $\mathrm{N}_{2} \mathrm{O}$. The presence of some measurable dissolved oxygen at times along with nitrate isotope values $\left(\delta^{15} \mathrm{~N}_{-} \mathrm{NO}_{3}=\right.$ $13.3 \%$ and $\delta^{18} \mathrm{O}_{-} \mathrm{NO}_{3}=6.2 \%$ ) is highly indicative that some nitrification of ammonia has occurred followed by denitrification of the resultant nitrate, although the process has not moved to complete removal of nitrate. Similarly, lower concentrations of ammonium and some nitrate are also found at GBH9 and along with $\mathrm{NO}_{2}$, albeit at low concentrations. This possibly suggests a lower rate of nitrification and no denitrification, since although $\mathrm{NO}_{2}$ is an intermediate product in both process, the nitrate has to be formed before it can be removed. GBH3 has a much higher $\delta^{15} \mathrm{~N}^{-\mathrm{NH}_{4}}$ value than the other two landfill monitoring boreholes, but it also has much lower $\mathrm{NH}_{4}{ }^{+}-\mathrm{N}$ concentrations. This might indicate some nitrification followed by complete conversion to $\mathrm{N}_{2}$ via denitrification. The absence of any intermediate products might suggest the reaction is complete so removing nitrogen from the system in a region where the water table is known to fluctuate.

OX14 and PTM23 have very similar $\delta^{15} \mathrm{~N}^{-\mathrm{NH}_{4}}$ values to the transect boreholes. Site OX14 has nitrification/denitrification intermediates which could explain a much lower ammonium concentration. PTM23 however also has a high ammonium concentration and it would appear that this site is impacted by the plume. The shallow boreholes at PTM21 and PTM24 have some of the lowest ammonium concentrations and relative to the other transect boreholes have slightly elevated $\delta^{15} \mathrm{~N}$ $\mathrm{NH}_{4}$ values which may be indicative of some nitrification/denitrification reactions. All of these sites have relatively high DO concentrations at some times of the year as well as higher $\mathrm{pH}$ values $(>7)$ which are more conducive to denitrifying bacteria (Thomas et al., 1994). Again, the absence of any intermediate products suggests the reaction is complete so removing nitrogen from the system in a region where the water table is known to fluctuate.

One might speculate that the relatively consistent $\delta^{15} \mathrm{~N}^{-\mathrm{NH}_{4}}$ values observed could be a result of nitrification, which would increase the delta value, and sorption which would decrease the delta value. However, given that the oxygen availability is generally low and that the sorption and nitrification processes would have to occur in fairly equal amounts (independent of concentration - see Figure 8) 
this does seem a somewhat unlikely scenario. Therefore, since there is no relationship between ammonium concentration and $\delta^{15} \mathrm{~N}^{-\mathrm{NH}_{4}}$, sorption on to clays can most probably be ruled out as an attenuation mechanism. Away from the main plume, and on the direct edge of the landfill, there is strong evidence for both nitrification and denitrification. However, this appears limited and restricted to pockets of groundwater table fluctuation, and the majority of ammonium in the plume is not effectively retarded by sorption, with concentrations only tempered by dilution. Where the aquifer remains saturated all year round (particularly at piezometer depths $C$ and $D$ ) the ammonium can be considered as conservative. For the floodplain to be a buffer zone for nitrogen, as would generally be the case in more rural environments (Burt et al. 1999), then it is clear the site conditions prevent this from occurring since in the landfill plume, there is insufficient dissolved oxygen to facilitate nitrification at depths greater than $1 \mathrm{~m}$.

The area of landfills/waste dumps on the River Thames floodplain in the Oxford area is significant (Figure 1); $1.05 \mathrm{~km}^{2}$ of the $15.87 \mathrm{~km}^{2}$ of floodplain. Making the assumption that the influx of $\mathrm{NH}_{4}-\mathrm{N}$ to the river via the gravel aquifer from the Burgess Field waste dump is representative of the remainder on the floodplain, behaving in a similarly conservative manner, it is possible to estimate the total influx due to all the landfills/waste dumps. This takes into account the volume of the landfill and the dilution where the landfill is not located by the river bank. The calculated flux along an approximately $8 \mathrm{~km}$ reach of the River Thames is estimated as $75 \mathrm{~kg}$ ammonium $\left(\mathrm{NH}_{4}\right)$ per day or over 27.5 tonnes per year. Assuming no additional in-stream processing, this influx would lead to a river concentration of close to $0.1 \mathrm{mg} / \mathrm{L}$ at the end of the reach compared with $0.06 \mathrm{mg} / \mathrm{L}$ at Port Meadow - or roughly $40 \%$ of total ammonia in river coming from legacy waste dumps.

\section{Conclusions}

A combination of nitrogen isotopes, nitrogen speciation and dissolved nitrous oxide has been used to understand the sources of nitrogen in a complex and heterogeneous peri-urban floodplain. Based on other nitrogen isotope studies, the dominant source of nitrogen is in the form of ammonium and this has been shown to have originated from a former domestic landfill which continues to act as a source of elevated nitrogen into the environment. Despite some evidence for denitrification in areas with water table fluctuations near to the landfill or on the fringes of the landfill plume, the prevalence of year round reducing conditions in the deeper $(>1 \mathrm{~m})$ floodplain has resulted in the transport of ammonium, with minimal biogeochemical processing or sorption to sediments, directly into a major river. Although the calculated flux is not a large contribution to the overall nitrogen in the River, it does represent the addition of a significant proportion $(\sim 10 \%$ but up to $15 \%$, Table 4$)$ of the total ammonium as the River goes past each landfill. Collectively this contribution to overall ammonium concentrations could be very high. This is a hitherto unconsidered source of river pollution from the peri-urban fringe. Given the large number of urban developments along the edge of floodplains and the associated historical and at times ad hoc waste dumps, this is likely to be a scenario reflected in many other parts of the developed world. Catchment management plans that encompass floodplains in the peri-urban environment need to take into account the likely risk to groundwater and surface water quality from these legacy landfills.

\section{Acknowledgments}

This work greatly benefitted from the diligent field work of Debbie Allen and Peter Williams (BGS) 
who, along with the authors, undertook field sampling under a range of challenging conditions. This paper is published with the permission of the Executive Director, British Geological Survey (NERC).

\section{References}

Addiscott, T.M, Whitmore, A.P. and Powlson, D.S. 1991. Farming, Fertilizers and the Nitrate Problem. CAB International: Wallingford; p. 170.

Böhlke, J.K., Smith, R.L., and Miller, D.N. 2006. Ammonium transport and reaction in contaminated groundwater: Application of isotope tracers and isotope fractionation studies. Water Resources Research 42, W05411, 1-19.

Boonstra, J., de Ridder, N.A. 1981 Numerical Modelling of Groundwater Basins. ILRI publ. 29. International Institute for Land Reclamation and Improvement, Wageningen

Booth, K.A., Linley, K.A. 2010. Geological Indicators of Flooding: User Guidance Notes. British Geological Survey Openfile Report, OR/10/064. 16pp.

Böttcher, J., Strbel, O., Voerkelius, S. and Schimidt, H.L. 1990. Using isotope fractionation of nitratenitrogen and nitrate-oxygen for evaluation of microbial denitrification in a sandy aquifer. Journal of Hydrology 114, 413-424.

Burt, T.P., Matchett, L.S., Goulding, K.W.T., Webster, C.P. and Haycock, N.E. 1999. Denitrification in riparian buffer zones: the role of floodplain hydrology. Hydrological Processes 13, 10, 1451-1463.

Burt, T.P., Bates, P.D., Stewart, M.D., Claxton, A.J., Anderson, M.G. and Price, D.A. 2002. Water table fluctuations within the floodplain of the River Severn, England. Journal of Hydrology $262,1-4,1-20$.

Burt, T.P., and Pinay, G., 2005. Linking hydrology and biogeochemistry in complex landscapes. Progress in Physical Geography 29(3): 297-316.

Burt, T.P., Howden, N.J.K., Worrall, F., Whelan, M.J. and Bieroza, M. 2011. Nitrate in United Kingdom Rivers: Policy and Its Outcomes Since 1970. Environmental Science and Technology 45, 1, 175-181.

Buss, S.R., Herbert, A.W., Morgan, P., Thornton, S.F., and Smith, J.W.N. 2004. A review of ammonium attenuation in soil and groundwater. Quarterly Journal of Engineering Geology and Hydrogeology 37, 347-359.

Ceazan, M.L., Thurman, E.M., and Smith, R.L. 1989. Retardation of ammonium and potassium transport through a contaminated sand and gravel aquifer: The role of cation exchange. Environmental Science and Technology 23, 1402-1408.

Christensen, T.H., Kjeldsen, P., Bjerg, P.L., Jensen, D.L., Christensen, J.B., Baun, A., Albrechtsen, H.J., and Heron, G. 2001. Biogeochemistry of landfill leachate plumes. Applied Geochemistry $16,659-718$.

Corniello, A., Ducci, D. and Ruggieri, G. 2007. Areal Identification of Groundwater Nitrate Contamination Sources in Periurban Areas. Journal of Soils and Sediments 7, 159-166. 
Delwiche, C.C. and Steyn, P.L. 1970. Nitrogen isotope fractionation in soils and microbial reactions. Environmental Science and Technology 4, 929-935.

DeSimone, L.A. and Howes, B.L.1998. Nitrogen transport and transformations in a shallow aquifer receiving wastewater discharge: A mass balance approach. Water Resources Research 34, 271-285.

Devito, K.J., Fitzgerald, D., Hill, A.R., and Arevena, R. 1999. Nitrate dynamics in relation to lithology and hydrologic flow path in a river riparian zone. Journal of Environmental Quality $29,1075-1084$.

Flipse, W.J. Jr. and Bonner, F.T. 1985. Nitrogen-isotope ratios of nitrate in ground water under fertilized fields, Lon Island, New York. Ground Water 23, 59-67.

Foster, S.S.D., Cripps, A.C. and Smith-Carington, A. 1982. Nitrate leaching to groundwater. Philosophical Transactions of the Royal Society of London Series B-Biological Sciences 296, $1082,477-489$.

Fukada T., Hiscock K.M., Dennis P.F., 2004. A dual-isotope approach to the nitrogen hydrochemistry of an urban aquifer. Applied Geochemistry 19, 709-719.

Galloway, D.F. 1999. Addressing the global nitrogen problem. Abstracts of paper of the American Chemical Society 218, U591-U591.

Galloway, J. N. Dentener, F. J. Capone, D.G., Boyer, E.W., Howarth, R.W., Seitzinger, S.P., Asner, G.P., Cleveland, C.C., Green, P.A.,Holland, E.A., Karl, D.M., Michaels, A.F., Porter, J.H., Townsend, A.R. and Vorosmarty, C.J. 2004. Nitrogen cycles: past, present and future. Biogeochemistry 70, 2, 153-226.

Gooddy, D.C., Withers, P.J.A., McDonald, H.G., and Chilton, P.J. 1998. Behaviour and impact of cow slurry beneath a storage lagoon: II. Chemical composition of chalk porewater after 18 years. Water, Air and Soil Pollution 107 (1/4), 51-72.

Gooddy, D.C., Clay, J.W. and Bottrell, S.H. 2002. Redox-driven changes in pore-water chemistry of the Chalk unsaturated zone beneath unlined cattle slurry lagoons. Applied Geochemistry 17, 903-921.

Gormly, J.R. and Spalding, R. 1979. Sources and concentrations of nitrate-nitrogen in ground water of the Central Platte Region, Nebraska. Ground Water 17, 291-301.

Haycock, N.E. and Burt, T.P. 1993. Role of floodplain sediments in reducing nitrate concentration of subsurface run-off: a case study from the Cotswolds, UK. Hydrological Processes 7, 287-295.

Heaton, T.H.E. 1986. Isotopic studies of nitrogen pollution in the hydrosphere and atmosphere - a review. Chemical Geology 59, 87-102.

Heaton, T.H.E., Trick, J.K., and Williams, G.M. 2005. Isotope and dissolved gas evidence for nitrogen attenuation in landfill leachate dispersing into a chalk aquifer. Applied Geochemistry 20, 933-945.

Harms, T.K. and Grimm N.B. 2008. Hot spots and hot moments of carbon and nitrogen dynamics in a semi-arid riparian zone. Journal of Geophysical Research - Biogeosciences 113

Lapworth, D.J., Gooddy, D.C., Kent, F., Heaton, T.H.E., Cole, S.J. and Allen, D. 2013. A combined geochemical and hydrological approach to understanding macronutrient sources. Journal of 
Hydrology 500, 226-242.

Lyngkild, J. and Christensen, T.H. 1992. Redox zones of a landfill leachate pollution plume (Vejen, Denmark). Journal of Contaminant Hydrology 10, 4, 273-289.

Jackson, B.M., Wheater, H.S., Wade, A.J., Butterfield, D., Mathias, S.A., Ireson, A.M., Butler, A.P., McIntyre, N.R. and Whitehead, R. 2007. Catchment-scale modelling of flow and nutrient transport in the Chalk unsaturated zone. Ecological Modelling 209, 1, 41-52.

Jackson, B.M., Browne, C.A., Butler, A.P., Peach, D.W., Wade, A.J., and Wheater, H.S. 2008. Nitrate transport in Chalk catchments: monitoring, modelling and policy implications. Environmental Science and Policy, 11, 2, 125-135.

Karamanos, R.E. and Rennie, D.A. 1978. Nitrogen isotope fractionation during ammonium exchange reactions with soil clay. Canadian Journal of Soil Science 58, 53-60.

Kendall, C. 1998 Tracing nitrogen sources and cycling in catchments. In: Isotope Tracers in Catchment Hydrology (Eds C. Kendall \& J.J. McDonnell), pp. 519-576. Elsevier, Amsterdam.

Lawrence, A.R., Gooddy, D.C., Kanatharana, P., Ramnarong, V. and Meesilp, W. 2000. Groundwater Evolution Beneath a Rapidly Developing City in South East Asia. Hydrogeology Journal 8 564-575.

Lorah, M.M., Cozzarelli, I.M. and Böhlke, J.K.. 2009. Biogeochemistry at a wetland sedimentalluvial aquifer interface in a landfill leachate plume. Journal of Contaminant Hydrology 105, 3-4, 99-117.

Macdonald, D.M.J., Dixon, A., Newell, A.J. and Hallaways, A. 2012a. Groundwater flooding within an urbanised flood plain. Journal of Flood Risk Management 5, 1, 68-80.

Macdonald, D.M.J., Griffiths K.J., Lapworth D.J., Williams P.J., Stuart M.E., Gooddy D.C. 2012b. Hydrogeochemical characterisation of a peri-urban floodplain: initial findings. British Geological Survey Internal Report, IR/12/049. 97pp.

MacDonald, A.M., Lapworth D.J., Hughes A.G., Auton C.A., Maurice L., Finlayson A. and Gooddy D.C., 2014. Groundwater, flooding and hydrological functioning in the Findhorn floodplain, Scotland. Hydrology Research In Press, doi:10.2166/nh.2014.185

Mariotti, A., Landreau, A. and Simon, B. 1988. ${ }^{15} \mathrm{~N}$ isotope biogeochemistry and natural attenuation processes in groundwater: Application to the chalk aquifer of northern-France. Geochimica et Cosmonchimica Acta 52, 1869-1878.

Marsh, T.J. and Hannaford, J. (Eds). 2008. UK Hydrometric Register. Hydrological data UK series. Centre for Ecology \& Hydrology. 210 pp.

Murray-Hudson, M., Wolski, P. and Ringrose, S. 2006. Scenarios of the impact of local and upstream changes in climate and water use on hydro-ecology in the Okavango Delta, Botswana. Journal of Hydrology 331, 1-2, 73-84.

McClain, M.E., E.W. Boyer, C.L. Dent, S.E. Gergel, N.B. Grimm, P.M. Groffman, S.C. Hart, J.W. Harvey, C.A. Johnston, E. Mayorga, W.H. McDowell, and G. Pinay, 2003. Biogeochemical Hot Spots and Hot Moments at the Interface of Terrestrial and Aquatic Ecosystems. Ecosystems 6, 301-312 
Oakes, D.B., Young, C.P. and Foster, S.S.D. 1981. The effects of farming practices on groundwater quality in the United Kingdom. Science of the Total Environment 21, 17-30.

Pinter, N. Environment - One step forward, two steps back on US floodplains. 2005. Science 308, 5719, 207-208.

Sebilo, M., Mayer, B., Grably, M., Billou, D. and Maritotti, A. 2004. The use of 'ammonium diffusion' method for $\delta^{15} \mathrm{~N}^{-\mathrm{NH}_{4}}{ }^{+}$and $\delta^{15} \mathrm{~N}^{-\mathrm{NO}_{3}}{ }^{-}$measurements: Comparison with other techniques. Environmental Chemistry 1, 99-103.

Silva, S.R., Kendall, C., Wilkison, D.H., Ziegler, A.C., Chang, C.C.Y. and Avanzino, R.J. 2000. A new method for collection of nitrate from fresh water and the analysis of nitrogen and oxygen isotope ratios. Journal of Hydrology 228, 22-36.

Sophocleous, M. 2002. Interactions between groundwater and surface water: the state of the science. Hydrogeology Journal 10, 1, 52-67.

Stuart, M.E. and Lapworth, D.J. 2011a. A review of processes important in the floodplain setting. British Geological Survey, 32pp. (OR/11/030)

Stuart, M.E, Gooddy, D.C, Bloomfield, J.P. and Williams, A.T. 2011b. A review of the impact of climate change on future nitrate concentrations in groundwater of the UK. Science of the Total Environment 409, 15, 2859-2873.

Thomas, K.L., Lloyd, D. and Boddy L. 1994. Effects of oxygen, pH and nitrate concentration on denitrification by Pseudomonas species. FEMS Microbiology Letters 118, 181-186.

Tockner, K. and Stanford, J.A. 2002. Riverine flood plains: present state and future trends. Environmental Conservation 29, 3, 308-330.

Wakida, F.T., and Lerner, D.N. 2005. Non-agricultural sources of groundwater nitrate: a review and case study. Water Research 39, 3-16.

Wang, L., Stuart, M.E., Bloomfield, J.P., Butcher, A.S., Gooddy, D.C,, McKenzie, A.A., Lewis, M.A. and Williams, A.T. 2012. Prediction of the arrival of peak nitrate concentrations at the water table at the regional scale in Great Britain. Hydrological Processes. 26, 226-239.

Wassenaar, L.I. 1995. Evaluation of the origin and fate of nitrate in the Abbotsford Aquifer using the isotopes of ${ }^{15} \mathrm{~N}$ and ${ }^{18} \mathrm{O}$ in $\mathrm{NO}_{3}{ }^{-}$. Applied Geochemistry 10, 391-405.

Werritty, A. 2006. Sustainable flood management: oxymoron or new paradigm? Area 38, 1, 16-23.

Whitehead, P.G. and Crossman, J. 2012. Macronutrient cycles and climate change: Key science areas and an international perspective. Science of the Total Environment 434, 13-17. 


\section{List of Figures}

Figure 1. The River Thames floodplain in the vicinity of the city of Oxford. BGS (C) NERC 2014. Contains Ordnance Survey data (C) Crown copyright and database rights 2014. Licensed landfill information was provided by the Environment Agency, UK.

Figure 2. a) Study area with monitoring network and groundwater level contours based on measurements made between 3 and 7 October 2011. Note, symbols for sites PTM26 to PTM31 indicate the centres of the piezometer nests. b) Simplified geological cross-section showing major topographic features and direction of landfill plume. BGS (C) NERC 2014. Contains Ordnance Survey data (C) Crown copyright and database rights 2014. Licensed landfill information was provided by the Environment Agency, UK.

Figure 3. Peri-urban floodplains in the catchment of the River Thames. BGS (C) NERC 2014. Contains Ordnance Survey data (C) Crown copyright and database rights 2014.

Figure 4. Groundwater sampling during flood events: a) exposed well-head, b) sampling equipment, and c) piezometer design.

Figure 5. Study area with average $\mathrm{NH}_{4}-\mathrm{N}$ concentrations in groundwater from the piezometers. Graduated symbols indicate spatial variability in $\mathrm{NH}_{4}-\mathrm{N}$ concentrations. Note, symbols for piezometers within the nests are offset to enable the concentrations within each to be visible; piezometer $\mathrm{C}$ is positioned in the centre of the nest, $\mathrm{D}$ to the south-west and $\mathrm{B}$, where measurements are available, to the north-east. BGS (C) NERC 2014. Contains Ordnance Survey data (C) Crown copyright and database rights 2014. Licensed landfill information was provided by the Environment Agency, UK.

Figure 6. Filled contour plot showing changes in average $\mathrm{NH}_{4}-\mathrm{N}$ concentrations in groundwater across both transects in Port Meadow.

Figure 7. Cross-plot of $\mathrm{NH}_{4}-\mathrm{N}$ vs $\mathrm{Cl}$ in the Port Meadow area combined over the study period. Sites are grouped as: GBH3, 5 and 9 - Landfill; OX14 and PTM11 - Up gradient; PTM26-PTM31 A\&B Shallow Plume; PTM26-PTM31 C\&D - Deep Plume.

Figure 8. $\delta^{15} \mathrm{~N}$ values and concentrations of $\mathrm{NH}_{4}{ }^{+}-\mathrm{N}$ in Port Meadow groundwaters. All unlabelled data points are from two main transects. 


\section{List of Tables}

Table 1. Parameters used to calculate flux from Burgess Field landfill to the River Thames through the floodplain sediments.

Table 2. Borehole construction details and on-site field measurements data for selected boreholes in the Port Meadow network. Mean values are presented with the range of concentrations found over the 12 sampling periods from May 2010 to August 2013 is shown in brackets. Measurements made in August 2013 shown in square brackets.

Table 3. Nitrogen species and isotopic data for selected boreholes in the Port Meadow network. Mean values are presented with the range of concentrations found over the 12 sampling periods from May 2010 to August 2013 is shown in brackets. Measurements made in August 2013 shown in square brackets.

Table 4. Determination of ammonium and total nitrogen flux from landfill site to River at Port Meadow. 


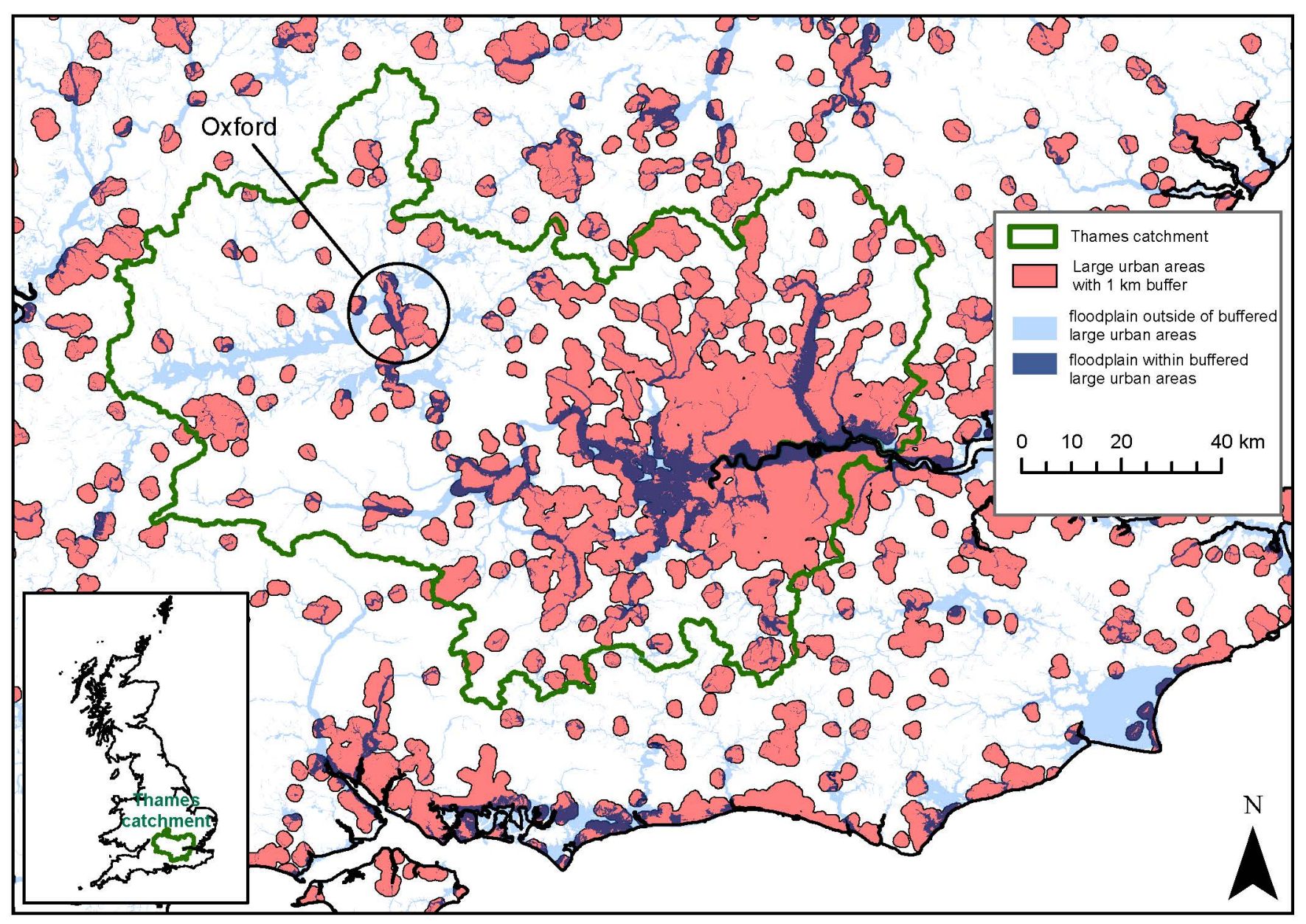




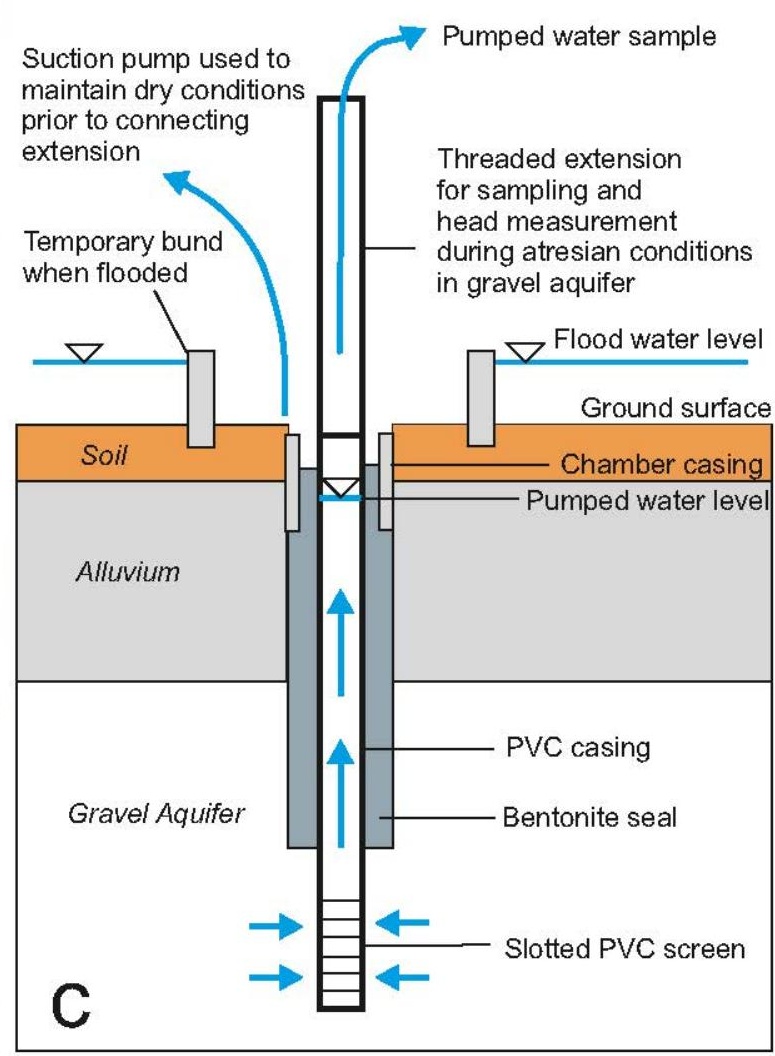




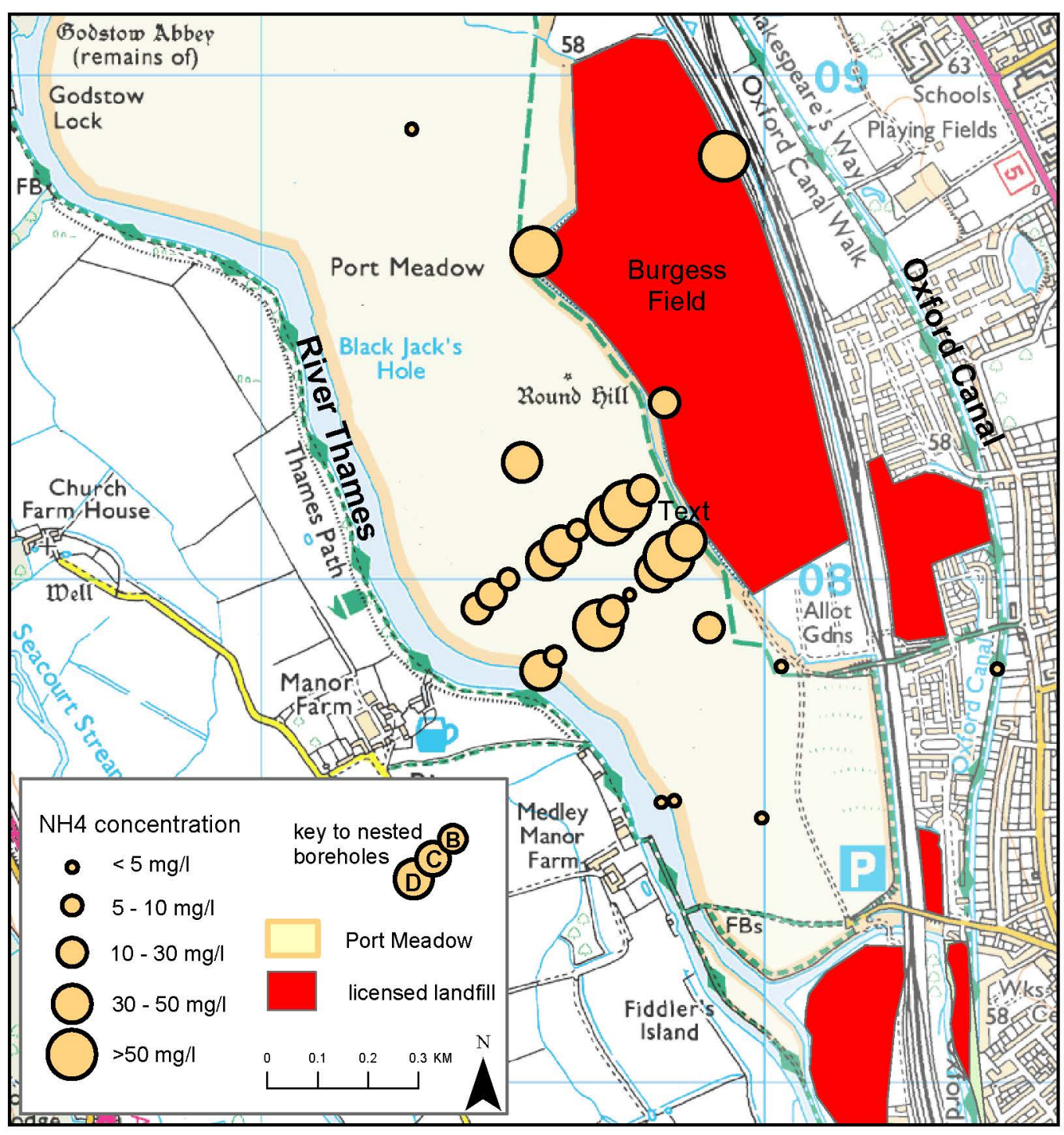




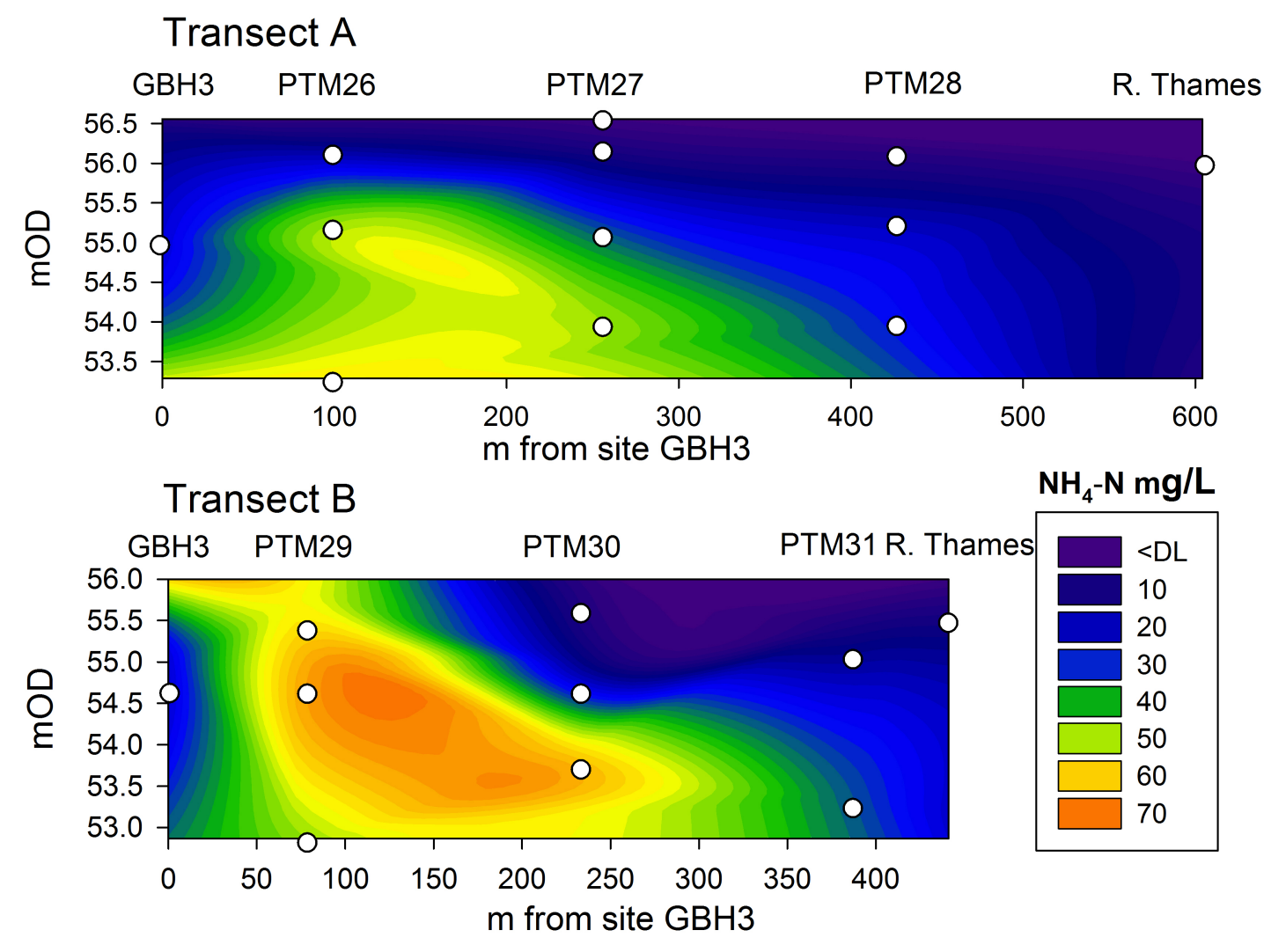




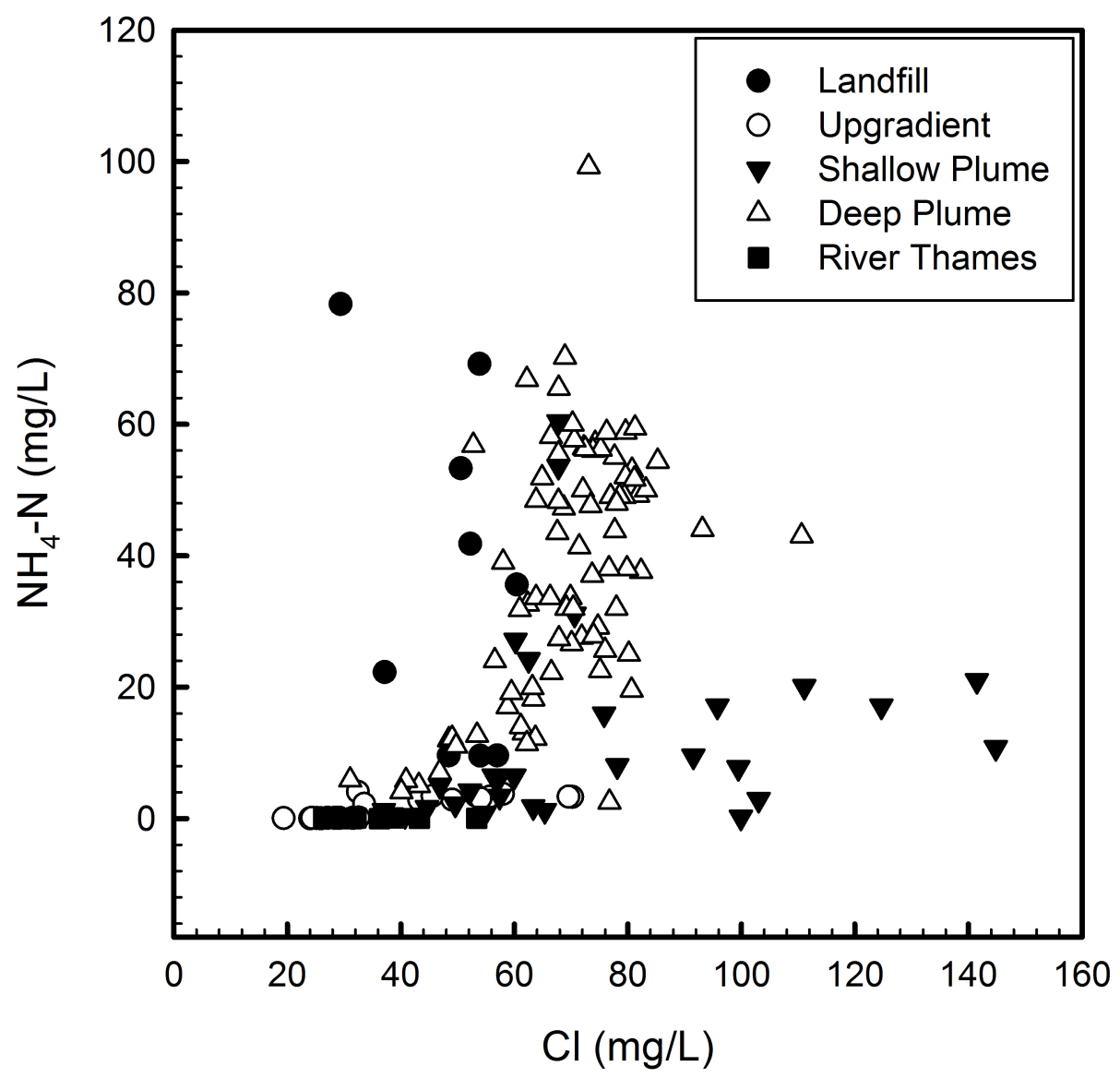




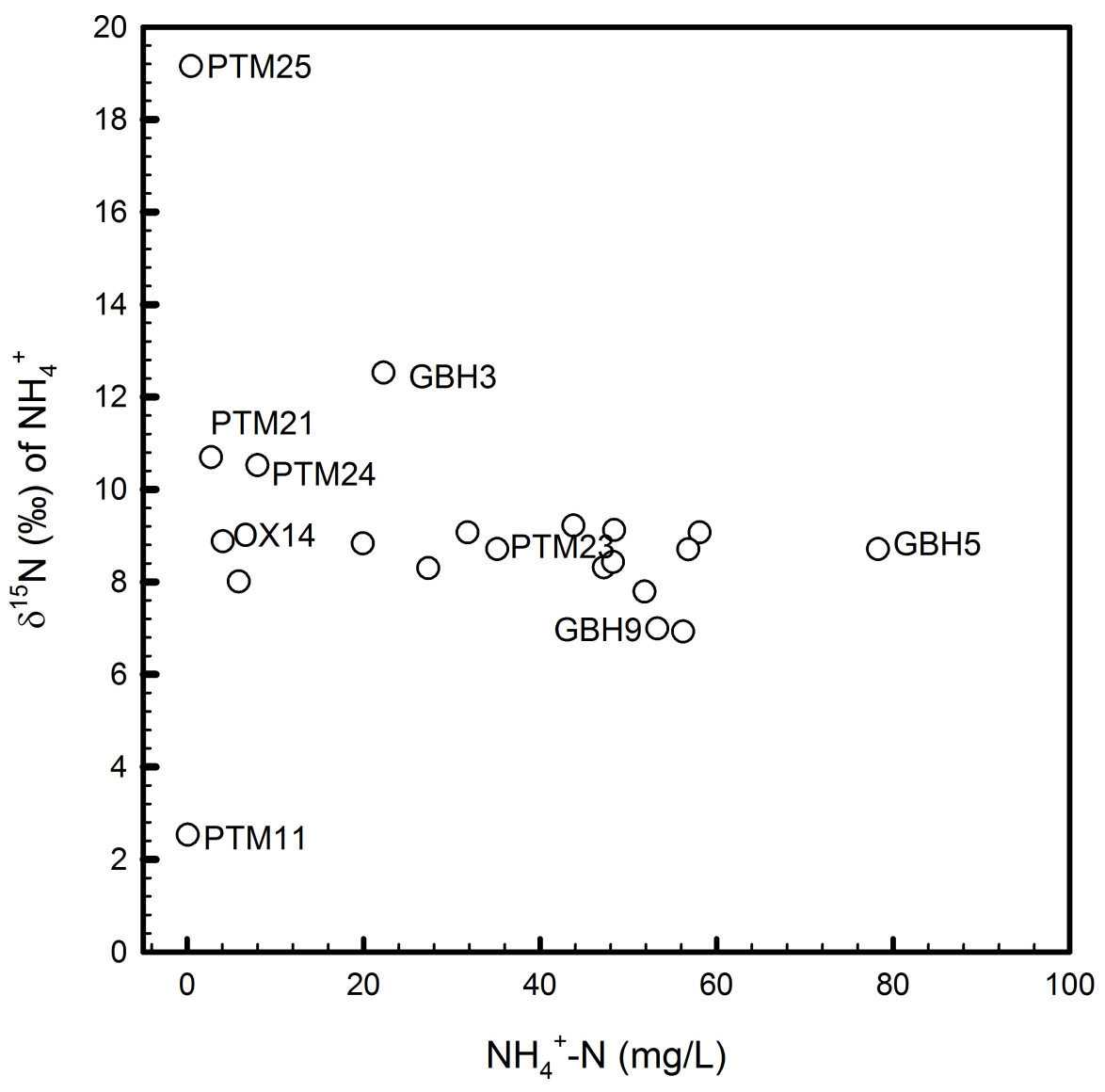


Table 1. Parameters used to calculate flux from Burgess Field landfill to the River Thames through the floodplain sediments.

\begin{tabular}{|l|l|}
\hline Parameters & Value \\
\hline Gravel aquifer hydraulic conductivity $(\mathrm{m} / \mathrm{d})$ & $400( \pm 200)$ \\
\hline Groundwater river inflow cross-sectional area $(\mathrm{m})$ & 2.5 \\
\hline Groundwater level gradient $(-)$ & 0.0004 \\
\hline landfill length, parallel to river $(\mathrm{m})$ & 1000 \\
\hline Groundwater inflow to river along affected reach $\left(\mathrm{m}^{3} / \mathrm{d}\right)$ & $400( \pm 200)$ \\
\hline Mean daily river flow $\left(\mathrm{m}^{3} / \mathrm{d}\right)$ & $1.60 \times 10^{6}$ \\
\hline
\end{tabular}


Table 2. Borehole construction details and on-site field measurements data for selected boreholes in the Port Meadow network. Mean values are presented with the range of concentrations found over the 12 sampling periods from May 2010 to August 2013 is shown in brackets. Measurements made in August 2013 shown in square brackets.

\begin{tabular}{|c|c|c|c|c|c|}
\hline Site & $\begin{array}{c}\text { Borehole } \\
\text { depth }^{\#} \\
\text { m }\end{array}$ & $\begin{array}{l}\text { Geology at } \\
\text { screen }\end{array}$ & $\begin{array}{l}\text { SEC } \\
\mu \mathrm{S} / \mathrm{cm}\end{array}$ & $\mathrm{pH}$ & $\begin{array}{l}\mathrm{DO} \\
\mathrm{mg} / \mathrm{L}\end{array}$ \\
\hline GBH3 & 5.09 & See note ${ }^{*}$ & 2027 (1944-2110) & $6.77(6.68-6.86)$ & $0.83(0.46-1.20)$ \\
\hline GBH5 & 5.60 & See note* & 1560 (1438-1681) & $6.94(6.68-7.19)$ & $0.14(<0.1-0.23)$ \\
\hline GBH9 & 5.24 & See note ${ }^{*}$ & $1463(1403-1522)$ & $6.86(6.68-7.03)$ & $0.38(0.26-0.50)$ \\
\hline OX14 & 2.72 & Gravel & 824 (743-977) [798] & $7.43(7.21-7.72)$ [7.34] & $0.64(0.19-2.04)[0.30]$ \\
\hline PTM11 & 3.38 & Gravel & $772(640-860)$ [755] & 7.21 (6.93-7.99) [6.93] & $0.40(<0.1-0.79)[0.22]$ \\
\hline PTM21 & 1.40 & Gravel & 1071 (914-1283) [1080] & 7.19 (6.87-7.67) [7.67] & $2.03(0.66-4.81)$ [0.69] \\
\hline PTM23 & 1.67 & Gravel & 1661 (957-1957) [1531] & 6.99 (6.81-7.40) [6.89] & $3.61(0.45-10.6)$ \\
\hline PTM24 & 0.99 & Gravel & 1075 (640-1250) [1180] & $6.89(6.65-7.18)$ [6.65] & $1.24(0.37-1.73)$ \\
\hline PTM25 & 0.93 & Gravel & 1336 (691-1622) [1350] & $6.92(6.61-7.45)$ [6.61] & $3.03(0.45-10.6)$ [0.63] \\
\hline PTM26B & 0.83 & Alluvium & 1277 (447-1530) & $6.91(6.59-7.26)$ & $0.64(<0.1-1.24)$ \\
\hline PTM26C & 1.69 & Gravel & 1625 (1548-1846) [1566] & $6.87(6.64-7.16)$ [6.69] & $0.43(<0.1-0.95)$ [0.28] \\
\hline PTM26D & 2.90 & Gravel & 1812 (1619-19850 [1705] & $6.86(6.64-7.17)$ [6.64] & $0.56(<0.1-1.33)[0.28]$ \\
\hline PTM27B & 0.76 & Alluvium & 1641 (1211-2060) [1821] & 7.08 (6.75-7.44) [7.09] & $0.62(<0$ \\
\hline PTM27C & 1.82 & Gravel & $1662(1005-2090)$ [1878] & $6.91(6.57-7.48)$ [6.61] & $0.52(<0.1-0.85)[0.41]$ \\
\hline PTM27D & 2.94 & Gravel & $1963(1854-2120)$ [1854] & $6.87(6.62-7.18)$ [6.65] & $0.38(<0.1-0.77)[0.25]$ \\
\hline PTM28B & 0.81 & Alluvium & 2263 (2010-2662) & $6.91(6.65-7.40)$ & $1.28(<0.1-3.6)$ \\
\hline PTM28C & 1.76 & Gravel & $1990(1835-2160)$ [2010] & $6.85(6.64-7.12)$ [6.77] & $0.89(<0.1-1.71)$ [0.83] \\
\hline PTM28D & 3.64 & Gravel & 1895 (1755-2160) [1783] & $6.83(6.68-7.11)$ [6.68] & $0.72(<0.1-3.02)[0.39]$ \\
\hline PTM29C & 1.62 & Gravel & 1209 (1106-1303) [1190] & $6.98(6.73-7.25)$ [6.76] & $0.38(<0.1-0.63)[0.26]$ \\
\hline PTM29D & 3.74 & Gravel & 1733 (1075-1949) [1773] & $6.90(6.64-7.26)$ [6.64] & $0.48(<0.1-1.00)[0.21]$ \\
\hline РТМ30В & 0.76 & Alluvium & $1168(955-1420)$ & $7.23(7.04-7.36)$ & $3.19(0.81-7.92)$ \\
\hline РТМ30С & 1.81 & Gravel & 1334 (688-1942) [1379] & $7.00(6.67-7.24)$ [6.67] & $0.56(<0.1-1.31)$ [0.47] \\
\hline PTM30D & 2.85 & Gravel & 1655 (911-1898) [1673] & $6.93(6.69-7.24)$ [6.69] & $0.49(<0.1-1.20)[0.46]$ \\
\hline РТМ31B & 0.86 & Alluvium & $1969(1577-2540)$ & $7.19(6.91-7.35)$ & $1.36(<0.1-2.93)$ \\
\hline РTM31C & 1.78 & Gravel & 1725 (1513-2050) [1590] & $6.96(6.72-7.25)$ [6.72] & $0.56(<0.1-1.35)[0.32]$ \\
\hline PTM31D & 3.87 & Gravel & 1745 (1140-1985) [1638] & $6.99(6.76-7.41)$ [6.76] & $0.39(<0.1-1.10)$ [0.39] \\
\hline R. Thames & $\mathrm{n} / \mathrm{a}$ & $\mathrm{n} / \mathrm{a}$ & $607(450-714)$ [583] & $8.19(7.42-8.67)$ [7.42] & $9.78(7.80-12.7)$ [9.46] \\
\hline
\end{tabular}

\# all screen sections are over the bottom $0.5 \mathrm{~m}$ of the borehole, apart from the GBH boreholes, drilled in the 1980s, for which no screen information is available

* GBH boreholes are drilled into the gravel; it is expected that they are screened in the gravel and also the overlying alluvium and landfill material 
Table 3. Nitrogen species and isotopic data for selected boreholes in the Port Meadow network. Mean values are presented with the range of concentrations found over the 12 sampling periods from May 2010 to August 2013 is shown in brackets. Measurements made in August 2013 shown in square brackets.

\begin{tabular}{|c|c|c|c|c|c|c|c|}
\hline Site & $\begin{array}{l}\mathrm{NO}_{3}-\mathrm{N} \\
\mathrm{mg} / \mathrm{L}\end{array}$ & $\begin{array}{l}\delta^{15} \mathrm{~N}-\mathrm{NO}_{3} \\
\% \text { о }\end{array}$ & $\begin{array}{l}\delta^{18} \mathrm{O}-\mathrm{NO}_{3} \\
\% \text { o }\end{array}$ & $\begin{array}{l}\mathrm{N}_{2} \mathrm{O} \\
\mu \mathrm{g} / \mathrm{L}\end{array}$ & $\begin{array}{l}\mathrm{NO}_{2} \\
\mu \mathrm{g} / \mathrm{L}\end{array}$ & $\begin{array}{l}\mathrm{NH}_{4}-\mathrm{N} \\
\mathrm{mg} / \mathrm{L}\end{array}$ & $\begin{array}{l}\delta^{15} \mathrm{~N}-\mathrm{NH}_{4} \\
\% \text { о }\end{array}$ \\
\hline GBH3 & $<0.01(<0.01-5.6)$ & & & 0.3 & $<10$ & $22(9.6-36)[14]$ & +12.5 \\
\hline GBH5 & $7.06(2.55-16.2)$ [13.3] & +13.3 & +6.2 & 27.9 & $<10$ & $69(9.6-78)$ [53] & +8.7 \\
\hline GBH9 & $16.5(0.82-48)$ [0.82] & +8.7 & & 19.9 & $<10(<10-170)$ & 42 (9.6-53) [39] & +7.0 \\
\hline OX14 & $0.12(<0.01-0.48)$ & & & $11.3(<0.1-13.5)$ & $<10(<10-90)$ & $3.3(2.8-4.1)[3.0]$ & +8.9 \\
\hline PTM11 & $0.03(<0.01-0.21)$ & & & $<0.1(<0.1-0.3)$ & $<10$ & $<0.2(<0.2-2.2)[0.2]$ & +2.5 \\
\hline PTM21 & $0.03(<0.0 .1-0.35)$ & & & NA & $<10$ & $2.7(1.58-6)[2.2]$ & +10.7 \\
\hline PTM23 & $0.12(<0.01-1.63)$ & & & NA & $<10(<10-30)$ & $11.5(0.45-35.2)$ [25] & +8.7 \\
\hline PTM24 & $0.02(<0.01-0.06)$ & & & NA & $<10$ & $3.3(1.9-7.9)[5.0]$ & +10.5 \\
\hline PTM25 & $0.1(<0.01-0.53)$ & & & 0.1 & $<10(<10-90)$ & $0.43(0.15-0.58)[0.4]$ & +19.2 \\
\hline РTM26B & $0.09(<0.01-0.38)$ & & & NA & $<10$ & $4.5(1.2-24.2)$ & NA \\
\hline PTM26C & $0.06(<0.01-0.32)$ & & & $27(<0.1-54)$ & $<10$ & $19(13-22)[14]$ & +8.8 \\
\hline PTM26D & $0.05(<0.01-0.3)$ & & & $1.75(0.88-2.6)$ & $<10(<10-50)$ & 27 (22-29) [18] & +8.3 \\
\hline PTM27B & $0.05(<0.01-2.8)$ & & & 10.7 (0.5-17.3) & $<10$ & $7.7(2.2-31)$ & NA \\
\hline PTM27C & $0.04(<0.01-0.36)$ & & & $1.8(0.9-2.8)$ & $<10(<10-50)$ & $33(12-47)$ [28] & +8.3 \\
\hline PTM27D & $0.03(<0.01-0.09)$ & & & $0.8(<0.1-1.5)$ & $<10$ & $48(2.5-50)[31]$ & +8.4 \\
\hline РTM28B & $0.08(<0.01-1.14)$ & & & NA & $<10$ & $17(2.9-27)$ & NA \\
\hline PTM28C & $0.09(<0.01-0.49)[0.49]$ & +3.7 & & 1.1 & $<10$ & 49 (43-99) [27] & +9.2 \\
\hline PTM28D & $0.06(<0.01-0.2)$ & & & $3.5(<0.1-39)$ & $<10$ & $56(49-56)[25]$ & +6.9 \\
\hline PTM29C & $0.04(<0.01-0.17)$ & & & $9.2(2.5-15.9)$ & $<10$ & 21.3.(5-28) [28] & +8.0 \\
\hline PTM29D & $0.03(<0.01-0.14)$ & & & $0.3(<0.1-0.3)$ & $<10$ & $32(5.8-37)[22]$ & +9.1 \\
\hline РТМ30В & $0.02(<0.01-25.5)$ & & & 1.12 & $<10(<10-2800)$ & $1.8(0.45-15.9)$ & NA \\
\hline РТМ30С & $0.05(<0.01-0.15)$ & & & 0.4 & $<10$ & $14(4-52)[41]$ & +7.8 \\
\hline PTM30D & $0.05(<0.01-0.51)$ & & & $0.2(0.1-0.3)$ & $<10$ & 58 (36-59) [36] & +9.1 \\
\hline РТМ31В & $0.07(<0.01-0.69)$ & & & NA & $<10$ & $54(1.2-60)$ & NA \\
\hline РTM31C & $0.08(<0.01-0.27)$ & & & $102(13.7-191)$ & $<10$ & $63(44-70)[44]$ & +8.7 \\
\hline
\end{tabular}


PTM31D $0.06(<0.01-0.14)$

R. Thames 21 (16.6-30) [18.4]
$0.6(0.2-1)$

NA
$<10$

$70(<10-140)$
$48(11-52)$ [39]

$0.06(<0.2-0.14)$
$+9.1$

NA 

Table 4. Determination of ammonium and total nitrogen flux from landfill site to River at Port Meadow.

\begin{tabular}{|l|l|l|}
\hline & Deep sample & $\begin{array}{l}\text { Average of shallow } \\
\text { and deep }\end{array}$ \\
\hline $\mathrm{NH}_{4}-\mathrm{N}$ groundwater concentration $\left(\mathrm{g} / \mathrm{m}^{3}\right)$ & 29.9 & 21.6 \\
\hline $\mathrm{NH}_{4}-\mathrm{N}$ influx to river $(\mathrm{g} / \mathrm{d})$ & $10000( \pm 5000)$ & $8600( \pm 4300)$ \\
\hline $\mathrm{NH}_{4}-\mathrm{N}$ river concentration $(\mathrm{g} / \mathrm{m} 3)$ & 0.064 & \\
\hline $\mathrm{NH}_{4}-\mathrm{N}$ flux within river $(\mathrm{g} / \mathrm{d})$ & $1.02 \times 10^{5}$ \\
\hline $\mathrm{N}$ river concentration $-\mathrm{NH}_{4}-\mathrm{N}+\mathrm{NO}_{3}-\mathrm{N}\left(\mathrm{g} / \mathrm{m}^{3}\right)$ & 5.45 & \\
\hline $\mathrm{N}$ flux within river $(\mathrm{g} / \mathrm{d})$ & $8.7 \times 10^{6}$ & \\
\hline $\mathrm{NH}_{4}-\mathrm{N}$ groundwater influx as percentage of river flux $(-)$ & $11.7( \pm 4.9)$ & $8.5( \pm 4.2)$ \\
\hline $\mathrm{N}$ groundwater influx as percentage of river flux $(-)$ & $0.14( \pm 0.07)$ & $0.10( \pm 0.05)$ \\
\hline
\end{tabular}

